\title{
The Estimation of Iron Oxide Content in Soil based on Landsat 8 OLI TIRS Imagery in Wetland Areas
}

\author{
Deasy Arisanty ${ }^{*}$, Aswin Nur Saputra ${ }^{1}$, Akhmad Munaya Rahman ${ }^{1}$, \\ Karunia Puji Hastuti ${ }^{1}$ and Dedi Rosadi ${ }^{2}$ \\ ${ }^{1}$ Department of Geography Education, Faculty of Teacher Training and Education, Lambung Mangkurat \\ University, Brigjend H. Hasan Basry Street, 70123 Banjarmasin, Indonesia \\ ${ }^{2}$ Department of Mathematics, Faculty of Mathematics and Natural Sciences, Gadjah Mada University, Sekip \\ Utara, 55281 Yogyakarta, Indonesia
}

\begin{abstract}
Wetland areas are volatile and have high iron content. In this study, through a remote sensing approach, especially using Landsat Operational Land Imager (OLI) and Thermal Infrared Sensor (TIRS) imagery, we discussed the method to estimate the presence of iron oxide in the wetlands of South Kalimantan in 2018, 2019, and 2020. Interpretation of the Landsat OLI TIRS was employed in April 2018, August 2018, February 2019, August 2019, March 2020, and August 2020. The band ratio method was used to determine the distribution of samples in this study. The results of the iron oxide index from the image were performed regression and correlation analysis with field measurement and laboratory test results to validate the oxide index values. The results showed that the iron oxide index value in the dry season was higher than in the rainy season. Iron oxide index value in open land was higher than in vegetation cover. The wetland was in dry condition during the dry season, making it easier to detect iron oxide values. Vegetation cover could reduce the iron oxide index value on the soil surface so that the iron oxide value was more easily identified in open land. The results of linear regression testing for the wet season sample

ARTICLE INFO

Article history:

Received: 23 April 2021

Accepted: 28 July 2021

Published: 22 October 2021

DOI: https://doi.org/10.47836/pjst.29.4.32

E-mail addresses:

deasyarisanty@ulm.ac.id (Deasy Arisanty)

aswin.saputra@ulm.ac.id (Aswin Nur Saputra)

munaya.rahman@ulm.ac.id (Akhmad Munaya Rahman)

karunia.puji@ulm.ac.id (Karunia Puji Hastuti) obtained a coefficient of determination $\mathrm{R}^{2}=$ 0.413 , while the results of linear regression testing for the dry season sample obtained a coefficient of determination $\mathrm{R}^{2}=0.667$. Thus, the Landsat image has strong enough to estimate the iron oxide index in the wetland area of Kalimantan.

Keywords: Iron oxide, Landsat 8 OLI TIRS, wetland
\end{abstract}

dedirosadi@ugm.ac.id (Dedi Rosadi)

* Corresponding author 


\section{INTRODUCTION}

Natural wetlands play an essential role in increasing the total dissolved Fe concentration (Guan et al., 2020). Iron (Fe) oxide is the most common metal oxide found in the soil. The Fe oxide surface is mainly covered with complex organic compounds that determine its reactivity and retention to the ions dissolved in the soil (Xing \& Niu, 2019). The reactivity of Fe is significantly increased in wetland soils (Davranche et al., 2013). Fe2O3 is formed by reacting oxygen in the atmosphere and the main Fe2+ mineral in the soil (Guo et al., 2020). The reduction and oxidation of iron in wetlands occur due to tidal fluctuations, especially in tidal swamps (Arisanty, 2017).

Data obtained through remote sensing can be used to investigate the components of the wetland ecosystem, one of which is soil data (Guo et al., 2017; Radeva et al., 2019; Sulaeman et al., 2020). Remote sensing allows identifying soil conditions by comparing the remote sensing data to the soil conditions in the field (Zhai, 2019). Remote sensing has been widely used for estimating soil characteristics based on sensors and different remote sensing techniques (Zribi et al., 2011). Soil data that can be identified through remote sensing is the iron content in the soil surface (Govil et al., 2018; Qing et al., 2019).

Landsat 8 OLI TIRS is a useful tool for researchers to collect research data (Ridwan et al., 2018). Landsat 8 OLI TIRS can be administered in soil mapping and is a crucial tool for soil observation, land planning, management, and precision agriculture (Meng et al., 2016; Silvero et al., 2021). Landsat imaging has been widely used in observing iron oxide content. The spectral response toward iron oxide content in the soil is the basis for estimating the distribution of iron oxide content used in estimating the iron oxide content in the Gunungsewu Karst area instead of using ALOS (Advanced Land Observing Satellite) AVNIR-2 (Advanced Visible and Near Infrared Radiometer type 2) (Nugroho \& Purwanto, 2013). In addition to determining the distribution of iron oxide content in the soil, Landsat TM has been found effective in carrying out detections than ALOS AVNIR-2.

Landsat 8 OLI TIRS can be used to calculate the correlation between iron oxide content in the soil and the possibility of hydrothermal alteration (Aisabokhae \& Oresajo, 2018; Putra et al., 2017). Red/blue band probes 6/7, 5/6 were performed to identify iron oxide minerals, clay minerals, carbonate minerals, and ferromagnesian (Pour \& Hashim, 2015). The Landsat 8 OLI TIRS can determine the distribution of iron oxide and hydroxide minerals that dominate the alluvium and ophiolite rocky areas (Darmawan et al., 2020). The spectral reference, which involves thermal sensors, can also be used in iron oxide identification (Haq, 2017). The combination of band ratio and land surface temperature method results in sound accuracy in iron oxide identification. Landsat 8 image processing methods such as band combination, band ratio, and principal component analysis proved accurate for identifying iron oxides (Frutuoso et al., 2021). Landsat data can be used for preliminary mapping of iron oxide before detailed fieldwork and before selecting sampling sites (D’Arcy et al., 2018). 
The iron oxide content in wetland areas can be analysed using remote sensing technology using Landsat 8 OLI TIRS. Landsat 8 OLI TIRS offers an easier way to identify the iron oxide content in the soil. The spectral value in the image can determine the iron oxide value in wetlands (Demattê et al., 2017). Iron oxide research using remote sensing is mostly carried out in dryland with low vegetation cover and mining areas. In contrast, in wetlands, especially in the Kalimantan area, it is still limited. Wetlands in the Kalimantan region have high vegetation cover and a significant seasonal effect on the land. Landsat imagery is easily accessible, available in a short time, temporal support, and the combination of band ratio can detect multi-temporal iron oxide, so this study uses Landsat 8 OLI TIRS imagery. This study estimated iron oxide content in wetlands in two seasons (dry and rainy) and different vegetation cover conditions (open and vegetated). Thus, the use of this image can be identified in seasonal variations and variations in vegetation cover conditions. This study aims to estimate the presence of iron oxide in the wetlands of South Kalimantan in 2018, 2019, and 2020.

\section{METHODS}

\section{Research Location}

This research was conducted in Banjarbaru, South Kalimantan Province, Indonesia. Banjarbaru is located on 325'40"S-328'37'S and 114'41'22'E-114'54'25'E. Wetlands in South Kalimantan, as the research area, especially in Banjarbaru, are usually dry in the dry season and flooding in the rainy season (Arisanty et al., 2019; Arisanty et al., 2020). The map of the research location is presented in Figure 1.

\section{Data}

The Landsat 8 OLI TIRS data used was in 2018, 2019, and 2020. The selected satellite imagery was in April 2018 in the rainy season, August 2018 in the dry season, February 2019 in the rainy season, August 2019 in the dry season, and land fires occur, March 2020 in the wet season, and August 2020 in the dry season. The consideration in choosing this image is that the image condition is relatively clear from cloud cover because Kalimantan is often covered by clouds, especially during the rainy season. The study site is usually dry in the dry season and inundated in the rainy season. Therefore, two different conditions caused the image used to predict iron oxide also in two seasons. The description of the dataset is presented in Table 1. The research location is presented in Figure 2.

The number of samples taken in this study was 12 samples. Samples were taken randomly to represent open land and vegetation coverage. Sample 1-4 illustrate the value of iron oxide on open land, while samples 5-12 are the iron oxide values in the vegetationcovered sample. The results of the oxide index were performed correlation and regression 


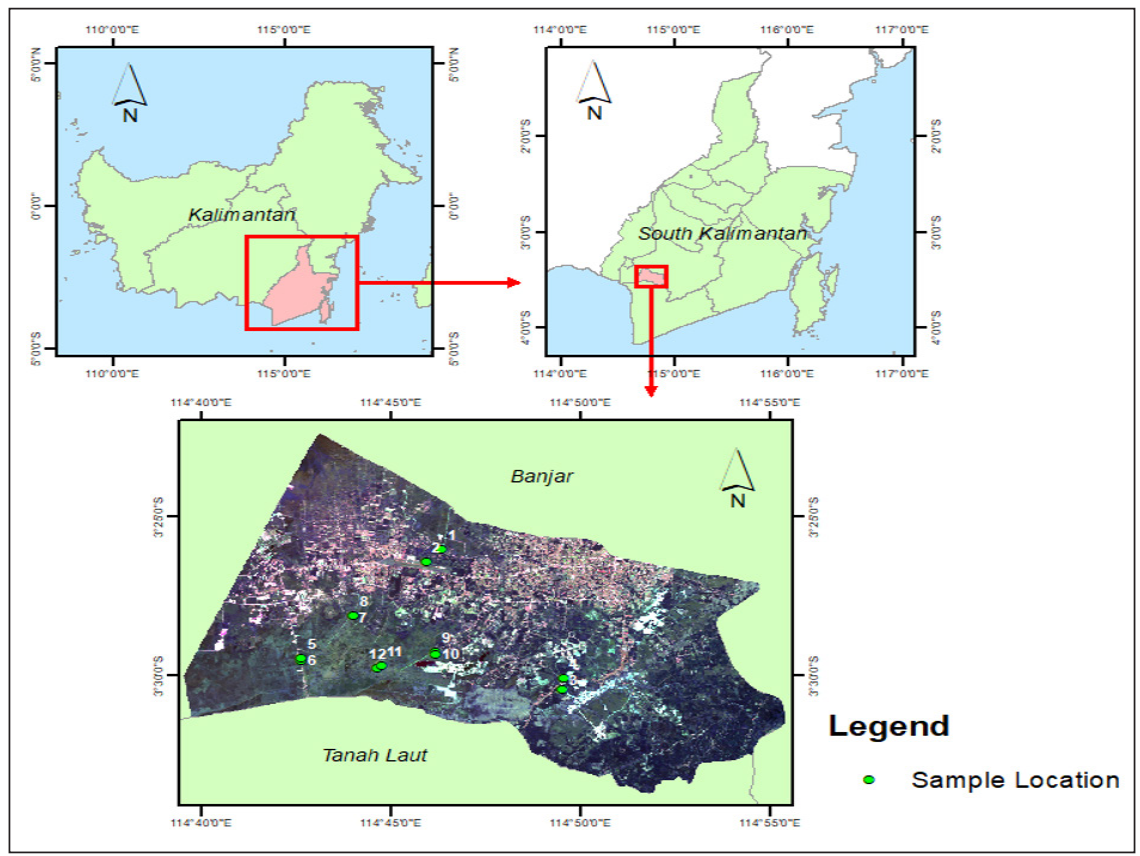

Figure 1. Map of research location in Banjarbaru

Table 1

The Description of the dataset

\begin{tabular}{llll}
\hline Acquisition time & Satellite & Sensor & Sources \\
\hline 2018.04 .30 & Landsat 8 & OLI/TIRS & USGS \\
2018.08 .20 & Landsat 8 & OLI/TIRS & USGS \\
2019.02 .28 & Landsat 8 & OLI/TIRS & USGS \\
2019.08 .23 & Landsat 8 & OLI/TIRS & USGS \\
2020.03 .02 & Landsat 8 & OLI/TIRS & USGS \\
2020.08 .09 & Landsat 8 & OLI/TIRS & USGS \\
\hline
\end{tabular}

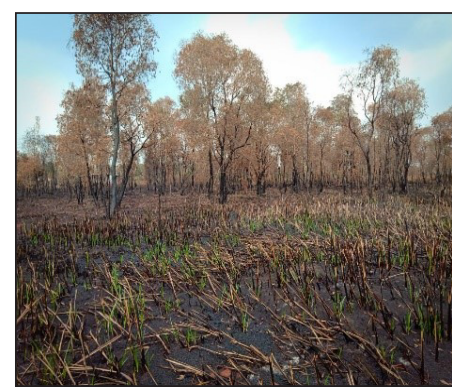

(a)

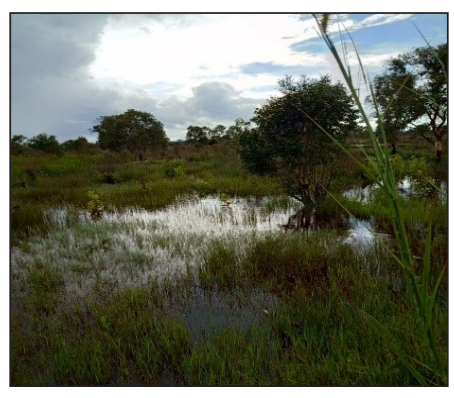

(b)

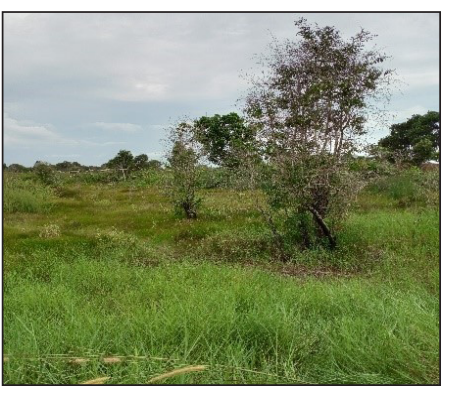

(c)

Figure 2. Research location: (a) August 2018 (Dry season); (b) February 2019 (Rainy season); and (c) August 2020 (Dry season). 
analysis with field measurement and laboratory test results to validate the oxide index values. The field sampling uses the hand bore to collect the soil sample. Analysis of Fe content using analysis of Ammonium Acetate (NH4OAc) extract.

\section{Imaging Correction}

The imaging correction process allows images to be refined before use. This correction improves image quality. The most common correction is a radiometric correction. The 1T level data had been corrected geometrically and automatically, while atmospheric disturbances had been removed. The conversion was carried out based on an algorithm proposed by the United States Geological Survey (USGS) (Ihlen, 2019) using the Envi 4.5 software.

The algorithm used to convert the DN image into a reflectance value is presented as Equation 1:

$\rho_{\lambda}^{\prime}=M_{\rho} * Q_{c a l}+A_{\rho}$

Remarks:

$\rho_{\lambda}{ }^{\prime}=$ Spectral reflectance, without concerning the sun angle

$M_{\rho}=$ Multiplicative reflectance-related factors in every band (REFLECTANCE_ MULT_BAND_n on metadata)

$A_{\rho}=$ Additive reflectance-related factors in every band (REFLECTANCE_ADD_ BAND_n on metadata)

$Q_{\text {cal }}=$ Image pixel score $(\mathrm{DN})$

After the image pixel score was converted into a reflectance value, solar angle correction was performed based on the equation proposed by USGS as Equation 2.

$$
\rho_{\lambda}=\frac{\rho_{\lambda^{\prime}}}{\sin (\theta)}
$$

Remarks:

$\rho_{\lambda}=$ Reflectant score after solar angle correction

$\theta=$ Sun elevation angle (SUN_ELEVATION from metadata)

The relative atmospheric correction using the dark object subtraction (DOS) method was then performed to produce an image with a surface reflectance value using ENVI 4.5 software (Kamal et al., 2012).

\section{Data Extraction Process}

In the data extraction stage, the information of remote sensing images was collected. Data extraction was carried out through digital image processing using spectral transformation in 
the band ratio method. In addition, the band ratio method employed an algorithm proposed in previous research, arranged, and used as a research mapping unit. The band ratio method determined the distribution of the samples of this study.

Strong reflection in the red spectrum, as opposed to strong absorption in the blue spectrum, should be highlighted concerning iron fraction minerals using the following ratio index (Equation 3).

$$
\text { Iron Oxidation }=\frac{\text { BVred }}{\text { BVblue }}
$$

Given that both the red and blue bands were subject to interference in the form of scatters in the atmosphere, where the minimum value that supposed to be zero become $>$ 0 , the following formula for the iron fraction index was used (Equation 4) (Liu \& Mason, 2009):

$$
\text { Iron Oxidation Index }=\frac{\text { BVred }-\min (\text { BVred })}{B V \text { blue }-\min (\text { BVblue })}
$$

\section{RESULTS}

\section{The Estimation of Iron Oxide Content at Different Seasons}

Table 2 and Figure 3 show the iron oxide content in 2018, 2019, and 2020. The mean value of the iron oxide index on April 30, 2018, was 0.980, and the iron oxide index on August 20, 2018, was 1.072. On February 28, 2019, the iron oxide index value was 0.952, and the iron oxide index value on august 23, 2019, was 1.012. On March 02, 2020, the iron oxide index value was 0.953, and on August 09, 2020, the iron oxide index value was 0.977. Based on the data, identifying iron oxide levels is better done in the dry season than in the rainy season because the iron oxide index value is high. In the rainy season, the land is inundated, while in the dry season, the land is dry. Therefore, tron oxide values are more predictable in the dry season in wetland areas than in a rainy season based on index value due to the value of iron oxide in dry season more than rainy season.

The image in the dry season is clearer from cloud cover than the image in the rainy season. The Kalimantan region is on the equator so that the cloud cover is very thick during the rainy season. The cloud masking process affects the iron oxide index value, which is difficult to remove, especially thin clouds. Analysis of iron oxide should be able to use images of the month entering the dry season. The clarity of the image coverage from the cloud cover also affected the image collection within a specific time. It was challenging to obtain clear image coverage without being influenced by the vast cloud cover at the beginning of the rainy season. The rainy season usually takes place from October to March.

Corrections are applied in the image to the surface reflectance level to interpret better the appearance of object values on the earth's surface. The corrected image is then subjected 


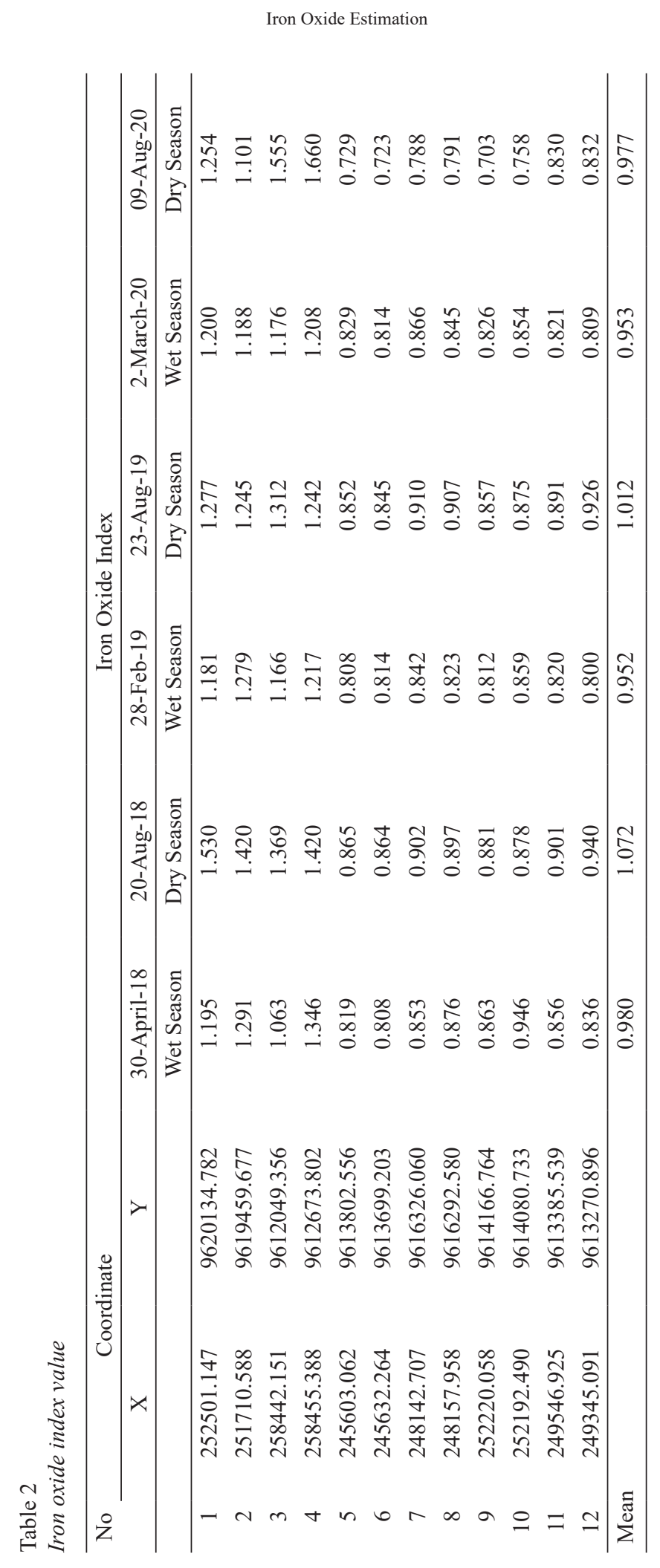

Pertanika J. Sci. \& Technol. 29 (4): 2829 - 2843 (2021) 


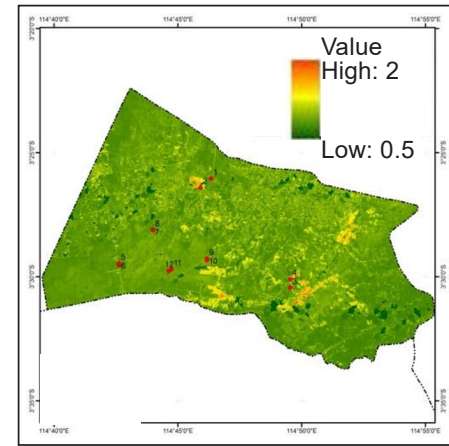

(a)

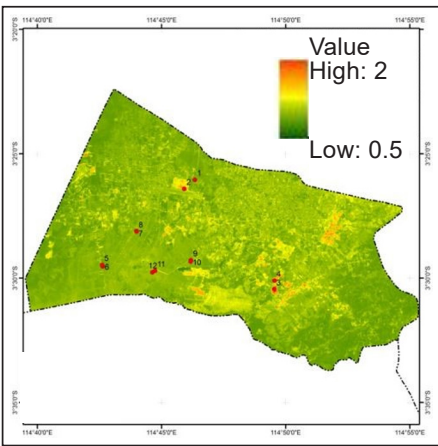

(d)

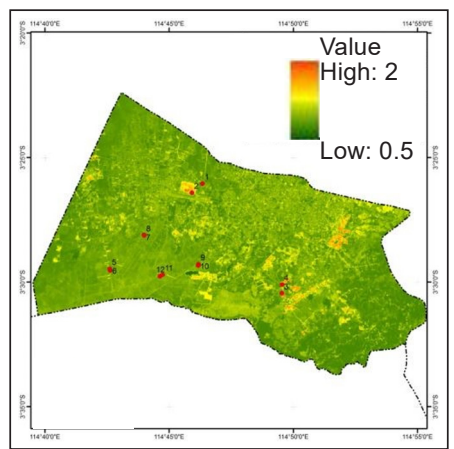

(b)

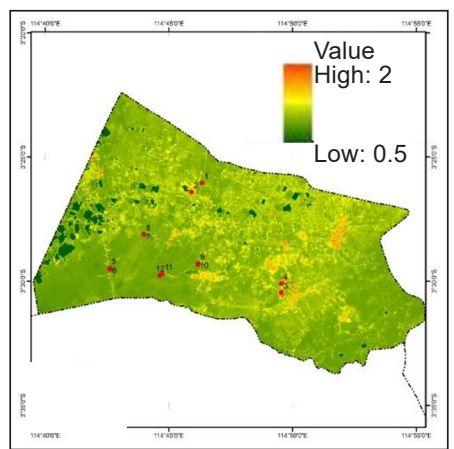

(e)

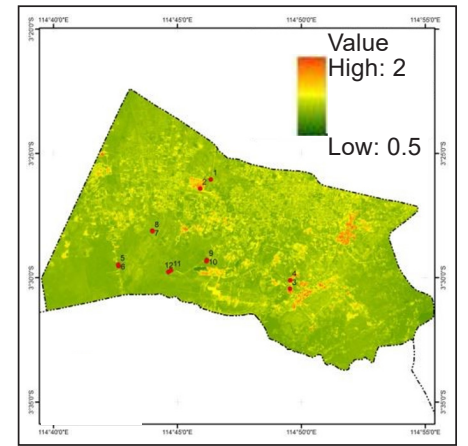

(c)

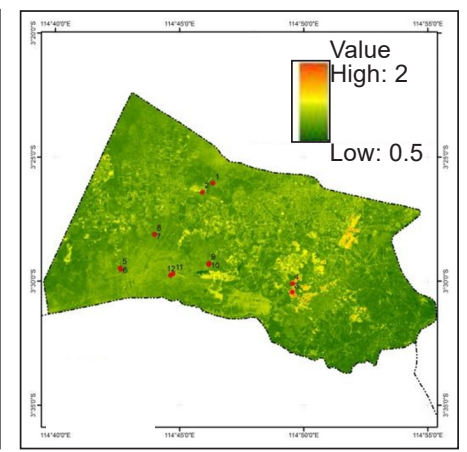

(f)

Figure 3. Iron oxide content map.: (a) April 30, 2018; (b) August 20, 2018; (c) February 28, 2019; (d) August 23, 2019, (e) March 2, 2020; (f) August 09, 2020

to spectral transformation using iron oxide index to highlight further the appearance of an iron oxide content on the soil surface.

\section{The Estimation of Iron Oxide Content based on Vegetation-Covered Condition}

The value of iron oxide on open land was higher than the value of iron oxide on land covered with vegetation. In Table 2, samples 1-4 illustrate the iron oxide value on open land, while samples 5-12 are the iron oxide values in the vegetation-covered sample. The value of iron oxide on the open land is more than 1, while on the land covered with vegetation, the value is less than 1 .

The vegetation cover on the soil surface also influences the detection of soil oxide content. Based on the observations of the band material, the index value of the oxide content is influenced by the vegetation cover in the area. Most high index values were mainly found in extremely low vegetation cover areas and those with no vegetation cover. The high vegetation cover will block the electromagnetic waves from touching the ground. If the waves reach the bottom, it will not be easy to reflect electromagnetic waves through the vegetation cover. Therefore, the vegetation cover has an effect on the value of iron oxide 
in the soil. In open land, iron content is more exposed than vegetated land. Moreover, the image interpretation value and the value of the iron content test in open land are higher than vegetation covered. Figures 4 and 5 describe the comparison of iron oxide values in various seasons and vegetation cover.

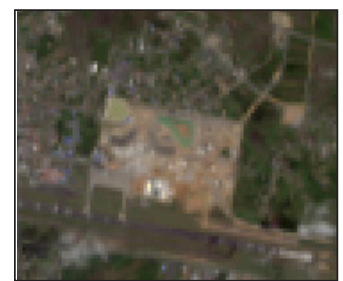

(a)

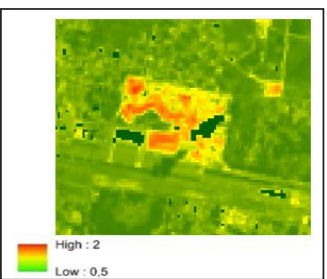

(b)

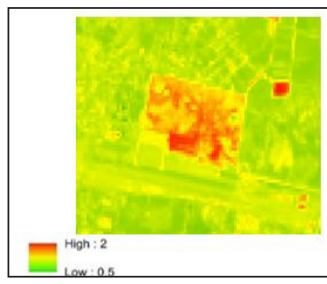

(c)

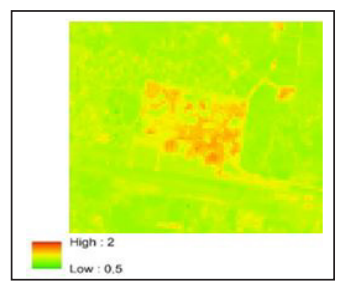

(d)

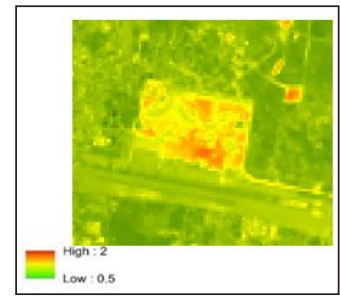

(e)

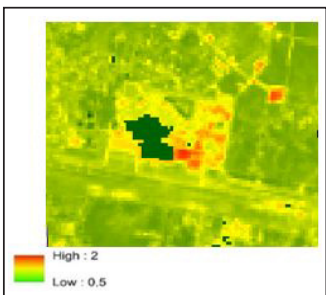

(f)

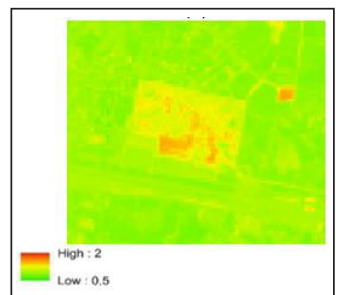

(g)

Figure 4. (a) Database Arcmap images; (b) Iron oxide transformation images on April 30, 2018; (c) Iron oxide transformation images on August 20, 2018; (d) Iron oxide transformation images on February 28, 2019; (e) Iron oxide transformation images on August 23, 2019; (f) Iron oxide transformation images on March 02, 2020; (g) Iron oxide transformation images on August 9, 2020. Comparison between the effects of open land and vegetated land on the spectral transformation of iron oxides.

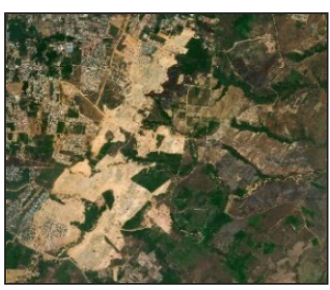

(a)

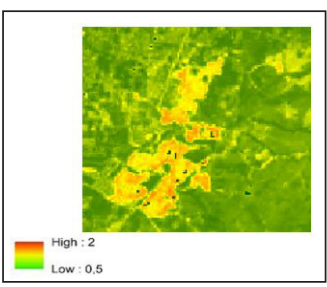

(b)

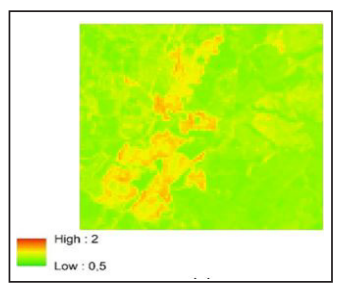

(c)

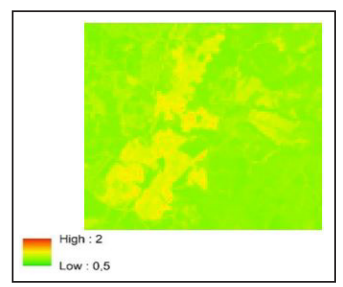

(d)

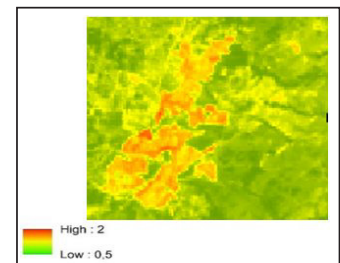

(e)

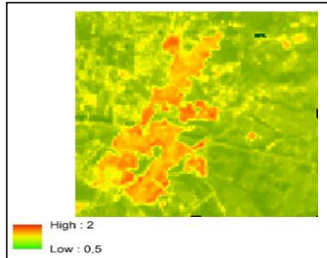

(f)

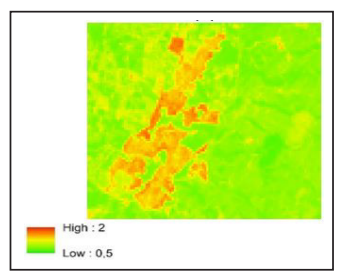

(g)

Figure 5. (a) Image true colour composite; (b) Iron oxide transformation images on April 30, 2018; (c) Iron oxide transformation images on August 20, 2018; (d) Iron oxide transformation images on February 28, 2019; (e)Iron oxide transformation images on August 23, 2019; (f) Iron oxide transformation images on March 02, 2020; (g) Iron oxide transformation images on August 9, 2020. Comparison between the effects of open land and vegetated land on the spectral transformation of iron oxides. 
As shown in Figures 4 and 5, the land cover in open land detected iron oxide content in the soil easier, the season when the coverage for the images was very influential on changes in the index value. Figures 4 and 5 illustrate the land covered in August, which coincided with the dry season (Figures 4c, 4e, 4g, 5c, 5e, \& 5g), in which the iron oxide was more clearly seen in open land areas with no vegetation cover. As a result, the colour of the open land becomes yellow-red, which indicates a high index value. Meanwhile, on vegetated land, the colour is green, which indicates a lower index value. In addition, the coverage image during the rainy season (Figures 4b, 4d, 4f, 5b, 5d, \& 5f) was correlated to the lower index value compared to the other images in the dry season. Based on those insights, it is highly recommended to conduct studies on iron oxide content through images during the dry season and open land. However, several factors should be considered in detecting the iron oxide content in the soil.

\section{The Validation of Iron Oxide Index Value}

The results of regression and correlation analysis were carried out on the samples from the iron content test. The samples tested were field samples in February 2019 and in August 2020. The data are tested for regression and correlation with the Landsat 8 image coverage in February 2019 and in August 2020. The Landsat 8 image was previously carried out by a spectral transformation process using the iron oxide index to highlight the appearance of iron oxide on the soil surface. The validation of the iron oxide index is presented in Table 3.

The results of linear regression testing for the February 2019 sample obtained a coefficient of determination $\mathrm{R}^{2}=0.413$ with a correlation of $\mathrm{r}=0.565$ and $\mathrm{P}$-value 0.0178 .

Table 3

The validation of the iron oxide index

\begin{tabular}{ccccc}
\hline \multirow{2}{*}{ No. } & \multicolumn{2}{c}{ February 2019 (Wet season) } & \multicolumn{2}{c}{ August 2020 (Dry season) } \\
\cline { 2 - 5 } & Field Survey $(\mathrm{ppm})$ & Images & Field Survey $(\mathrm{ppm})$ & Images \\
\hline 1 & 2200.74 & 1.181 & 6394.23 & 1.254 \\
2 & 105.36 & 1.279 & 3822.12 & 1.101 \\
3 & 150.11 & 1.166 & 2826.92 & 1.555 \\
4 & 2200.74 & 1.217 & 1971.15 & 1.660 \\
5 & 265.45 & 0.808 & 1793.27 & 0.729 \\
6 & 305.89 & 0.814 & 1514.42 & 0.723 \\
7 & 332.53 & 0.842 & 1471.15 & 0.788 \\
8 & 344.78 & 0.823 & 1250.00 & 0.791 \\
9 & 30.39 & 0.812 & 967.31 & 0.703 \\
10 & 105.36 & 0.859 & 279.81 & 0.758 \\
11 & 150.11 & 0.820 & 231.73 & 0.830 \\
12 & 30.39 & 0.800 & 153.37 & 0.832 \\
\hline
\end{tabular}

Source: Laboratory test and interpretation Landsat 8 OLI TIRS (2021); (Arisanty et al., 2020) 
The P-value $<\alpha, 0.0178<0.05$, means that image interpretation results can be used to predict the value of iron oxide in the wet season. The results of linear regression testing for the August 2020 sample obtained a coefficient of determination $\mathrm{R}^{2}=0.667$ with a correlation of $\mathrm{r}=0.530$ and $\mathrm{P}$-value 0.00066 . The $\mathrm{P}$-value $<\alpha, 0.00066<0.05$, means that the image interpretation results can be used to predict the value of iron oxide in the dry season. The regression value of iron oxide content is presented in Table 4.

Based on the test results, the sample in February 2019 and August 2020 has a strong enough influence and relationship with the image of the iron oxide index. It shows that the Landsat 8 image with the iron oxide index spectral transformation process can match the iron oxide content test results, especially the image in the dry season. Some things that must be considered in applying the image are the condition of cloud cover during image coverage, especially when entering the rainy season. In addition, the level of vegetation cover when determining the sample needs to be considered so as not to obstruct the monitoring of the iron oxide content found on the soil surface.

Table 4

Regression value of iron oxide content

\begin{tabular}{lclc}
\hline Regression Statistics (February & 2019/Wet Season) & \multicolumn{1}{c}{ Regression Statistics (August 2020/Dry Season) } \\
\hline Multiple R & 0.642 & Multiple R & 0.816 \\
R Square & 0.413 & R Square & 0.667 \\
Adjusted R Square & 0.322 & Adjusted R Square & 0.575 \\
Standard Error & 0.775 & Standard Error & 0.620 \\
Observations & 12 & Observations & 12 \\
\hline
\end{tabular}

\section{DISCUSSIONS}

Landsat 8 OLI TIRS image can detect erroneous mineral clusters, especially in seasonally dry areas (Rockwell, 2013). Therefore, field testing is necessary to improve detection quality. Nonetheless, Landsat 8 OLI TIRS images showed good performance for iron oxide exploration, even in crowded vegetation areas (Ducart et al., 2016; Zabloskii, 2019). Besides, the Landsat 8 OLI TIRS is highly useful for low-cost mapping purposes and use in remote areas (Traore et al., 2020).

The reflection of electromagnetic waves was the basis for oxide content detection in the soil. On the surface, soil surfaces containing oxides will show higher reflection values in the blue band $(400 \mathrm{~nm}$ to $500 \mathrm{~nm})$ and the red band $(600 \mathrm{~nm}$ to $700 \mathrm{~nm})$. Therefore, during the field checks, metal roofs were detected to have a high index value in the transformed image. Hence, it is necessary to further study the image transformation results from open land to be used as the basis for the determination of correlation between index value and the soil oxide content. 
The variation in the value of the spectral response shown in the open ground is also possible due to moisture content, organic matter, and particle size (Cardoso et al., 2014). Other vital variables are organic carbon content, particle size, and mineralogical composition (Demattê et al., 2017). The use of band 4 (600 nm to $700 \mathrm{~nm}$ ) and band 2 (400 $\mathrm{nm}$ to $500 \mathrm{~nm}$ ) appears to be quite effective in identifying iron oxide content in open ground.

Iron oxide and vegetation have a similar reflection spectrum in the wavelength region of bands 1 and 2 in the Landsat 8 OLI TIRS image and a slight difference in band 3 . The peak values of vegetation have similar values to goethite minerals in band 3 (Traore et al., 2020). In contrast, in band 3 , the reflectance value of hematite minerals was lower than that of goethite and vegetation. Therefore, the three bands are not suitable for identifying iron oxide with high vegetation cover in the land. Band 4 in the Landsat 8 OLI TIRS image, iron oxide and clay minerals have high reflectance and, conversely, chlorophyll from green plants absorbs intense radiation at red wavelengths (band 4). Moist vegetation has more radiation absorption in band 7 , and high reflectance by plant tissues at near-infrared wavelengths (band 5). In the spectral scope of band 5 in the Landsat 8 OLI image, the dominant iron oxide shows more radiation absorption. The high value in the $4 / 2$ band ratio helps detect the absorption of radiation values for iron oxide in the blue wavelength range. The band 4 and band 2 band ratios provide greater sensitivity to iron content even in low concentrations. However, the high value of this band ratio only highlights the iron oxide associated with the mafic regolith layer, not including the higher quality iron ore content (Ducart et al., 2016).

Mapping of this iron oxide both in open areas and under vegetation cover plays a crucial role. The role of iron oxide mapping can estimate the iron oxide deposits in the wetlands. Landsat utilisation for iron oxide estimation in wetlands has the highest $\mathrm{R}^{2}$ value (Guo et al., 2020). Spectrum values can identify wetland soil pedogenetic associated with variations in iron oxide (Demattê et al., 2017). The method can be an alternative for mineral mapping, saving costs, risks, and time. Spatial information determines the quality of data in a study. Spatial data can make it easier to research at a low cost (Rozpondek et al., 2016).

\section{CONCLUSIONS}

The iron oxide index value in wetlands can be estimated using Landsat OLI TIRS imagery. The results of this study have proven that this image can estimate the value of iron oxide in the wetlands. Estimation of iron oxide in wetland is better done in the dry season image because the land is in dry condition, and cloud cover can affect the value of the iron oxide index. Besides, areas covered with vegetation also have a lower value than open land, so it is better to identify them on open land than under vegetation cover. The recommendation is to use this Landsat OLI TIRS with different land conditions and with various land covers to determine the ability of Landsat OLI TIRS imagery to estimate the iron oxide under multiple conditions. 


\section{ACKNOWLEDGMENTS}

This research is funded by Lambung Mangkurat University, Research Grand Number 212.38/UN8.2/PL/2020.

\section{REFERENCES}

Aisabokhae, J. E., \& Oresajo, S. B. (2018). Supervised classification of Landsat-8 band ratio images for geological interpretation of Sokoto, Nigeria. South African Journal of Geomatics, 7(3), 360-371.

Arisanty, D. (2017). The influence of tide on suspended sediment transport in barito delta, Southern Kalimantan, Indonesia. Ecology, Environment and Conservation, 23(2), 696-703.

Arisanty, D., Adyatma, S., Muhaimin, M., \& Nursaputra, A. (2019). Landsat 8 OLI TIRS imagery ability for monitoring post forest fire changes. Pertanika Journal of Science \& Technology, 27(3), 1105-1120.

Arisanty, D., Jędrasiak, K., Rajiani, I., \& Grabara, J. (2020). The destructive impact of burned peatlands to physical and chemical properties of soil. Acta Montanistica Slovaca, 25(2), 213-223. https://doi. org/10.46544/AMS.v25i2.8

Cardoso, G. F., Souza, C., \& Souza-Filho, P. W. M. (2014). Using spectral analysis of Landsat-5 TM images to map coastal wetlands in the Amazon River mouth, Brazil. Wetlands Ecology and Management, 22(1), 79-92. https://doi.org/10.1007/s11273-013-9324-4

D’Arcy, M., Mason, P. J., Roda-Boluda, D. C., Whittaker, A. C., Lewis, J. M. T., \& Najorka, J. (2018). Alluvial fan surface ages recorded by Landsat-8 imagery in Owens Valley, California. Remote Sensing of Environment, 216, 401-414. https://doi.org/10.1016/j.rse.2018.07.013

Darmawan, I. G. B., Yassar, M. F., Elvarani, A. Y., Vira, B. A., \& Damayanti, L. (2020). Preliminary study of mining material prospects based on hydrothermal alteration distribution using composite and density slicing of Landsat 8 image in Ulubongka Regency, Central Sulawesi. PROMINE, 8(1), 1-7. https://doi. org/10.33019/promine.v8i1.1799

Davranche, M., Dia, A., Fakih, M., Nowack, B., Gruau, G., Ona-nguema, G., Petitjean, P., Martin, S., \& Hochreutener, R. (2013). Organic matter control on the reactivity of Fe (III)-oxyhydroxides and associated As in wetland soils: A kinetic modeling study. Chemical Geology, 335, 24-35. https://doi.org/10.1016/j. chemgeo.2012.10.040

Demattê, J. A. M., Horák-Terra, I., Beirigo, R. M., da Silva Terra, F., Marques, K. P. P., Fongaro, C. T., Silva, A. C., \& Vidal-Torrado, P. (2017). Genesis and properties of wetland soils by VIS-NIR-SWIR as a technique for environmental monitoring. Journal of Environmental Management, 197, 50-62. https:// doi.org/10.1016/j.jenvman.2017.03.014

Ducart, D. F., Silva, A. M., Toledo, C. L. B., \& de Assis, L. M. (2016). Mapping iron oxides with Landsat-8/ OLI and EO-1/Hyperion imagery from the Serra Norte iron deposits in the Carajás Mineral Province, Brazil. Brazilian Journal of Geology, 46(3), 331-349. https://doi.org/10.1590/2317-4889201620160023

Frutuoso, R., Lima, A., \& Teodoro, A. C. (2021). Application of remote sensing data in gold exploration: Targeting hydrothermal alteration using Landsat 8 imagery in northern Portugal. Arabian Journal of Geosciences, 14(6), 1-18. https://doi.org/10.14419/ijbas.v3i3.2821 
Govil, H., Tripathi, M. K., Diwan, P., \& Guha, S. (2018). Identification of iron oxides minerals in Western Jahajpur Region, India using aviris-ng hyperspectral remote sensing. International Archives of the Photogrammetry, Remote Sensing \& Spatial Information Sciences, 43(5), 233237. https://doi.org/10.5194/ isprs-archives-XLII-5-233-2018

Guan, J., Qi, K., Wang, J., Zhuang, J., Yuan, X., Yan, B., Lu, N., \& Qu, J. (2020). Effects of conversion from boreal natural wetlands to rice paddy fields on the dynamics of total dissolved iron during extreme precipitation events. Chemosphere, 242, Article 125153. https://doi.org/10.1016/j.chemosphere.2019.125153

Guo, B., Zang, W., Luo, W., Wen, Y., Yang, F., Han, B., Fan, Y., Chen, X., Qi, Z., \& Wang, Z. (2020). Detection model of soil salinization information in the Yellow River Delta based on feature space models with typical surface parameters derived from Landsat 8 OLI image. Geomatics, Natural Hazards and Risk, 11(1), 288-300. https://doi.org/10.1080/19475705.2020.1721573

Guo, M., Li, J., Sheng, C., Xu, J., \& Wu, L. (2017). A review of wetland remote sensing. Sensors, 17(4), Article 777. https://doi.org/10.3390/s17040777

Haq, M. A. (2017). Analysis of land surface temperature, distribution of clay minerals and fault fracture density using Landsat 8 imagery in the Dieng geothermal system and its surroundings, Central Java Province, Indonesia (Doctoral dissertation). Faculty of Engineering, Diponegoro University, Semarang, Indonesia.

Ihlen, V. (2019). Landsat 8 data users handbook. U.S. Geological Survey. USGS Publication.

Kamal, M., Adi, N. S., \& Arjasakusuma, S. (2012). Jaz EL-350 VIS NIR portable spectrometer: Panduan operasional pengukuran dan pengelolaan data pantulan spektral obyek (Versi 1 2012) [Jaz EL-350 VIS NIR portable spectrometer: Operational guide for spectral object data measuring and managing (Version 1/2012)]. Universitas Gadjah Mada.

Liu, J. G., \& Mason, P. J. (2009). Essential image processing and GIS for remote sensing (1st Edit). Wiley Online Library. https://doi.org/10.1002/9781118687963

Meng, L., Zhou, S., Zhang, H., \& Bi, X. (2016). Estimating soil salinity in different landscapes of the Yellow River Delta through Landsat OLI/TIRS and ETM+ Data. Journal of Coastal Conservation, 20(4), 271279. https://doi.org/10.1007/s11852-016-0437-9

Nugroho, Y. A., \& Purwanto, T. H. (2013). Study of estimation iron oxide content using mutispectral medium resolution imagery. Jurnal Bumi Indonesia, 2(3), 117-126.

Pour, A. B., \& Hashim, M. (2015). Hydrothermal alteration mapping from Landsat-8 data, Sar Cheshmeh copper mining district, south-eastern Islamic Republic of Iran. Journal of Taibah University for Science, 9(2), 155-166. https://doi.org/10.1016/j.jtusci.2014.11.008

Putra, I. D., Nasution, R. A. F., \& Harijoko, A. (2017). Aplikasi Landsat 8 OLI/TIRS dalam mengidentifikasi alterasi hidrotermal skala regional: studi kasus Daerah Rejang Lebong dan sekitarnya, Provinsi Bengkulu [Landsat 8 OLI/TIRS application in identifying regional scale hydrothermal alterations: A case study]. Proseding Seminar Nasional Kebumian, 10, 1812-1826.

Qing, K., Zhao, Y. J., \& Cui, X. (2019). Research on information extraction technology of iron oxide based on airborne hyperspectral data. In IGARSS 2019-2019 IEEE International Geoscience and Remote Sensing Symposium (pp. 6764-6767). IEEE Publishing. https://doi.org/10.1109/IGARSS.2019.8900647 
Radeva, K., Velizarova, E., \& Dancheva, A. (2019). Land cover monitoring as part of a survey on wetland ecosystem conservation in the Negovan village area using remote sensing tools. Glasnik Sumarskog Fakulteta, 119, 175-188. https://doi.org/10.2298/GSF1919175R

Ridwan, M. A., Radzi, N. A. M., Ahmad, W., Mustafa, I. S., Din, N. M., Jalil, Y. E., Isa, A. M., Othman, N. S., \& Zaki, W. (2018). Applications of landsat-8 data: A Survey. International Journal of Engineering \& Technology, 7(4), 436-441. https://doi.org/10.14419/ijet.v7i4.35.22858

Rockwell, B. W. (2013). Automated mapping of mineral groups and green vegetation from Landsat Thematic Mapper imagery with an example from the San Juan Mountains, Colorado. US Geological Survey Scientific Investigations Map.

Rozpondek, R., Wancisiewicz, K., \& Kacprzak, M. (2016). GIS in the studies of soil and water environment. Journal of Ecological Engineering, 17(3), 134-142. https://doi.org/10.12911/22998993/63476

Silvero, N. E. Q., Demattê, J. A. M., Amorim, M. T. A., dos Santos, N. V., Rizzo, R., Safanelli, J. L., Poppiel, R. R., de Sousa Mendes, W., \& Bonfatti, B. R. (2021). Soil variability and quantification based on Sentinel-2 and Landsat-8 bare soil images: A comparison. Remote Sensing of Environment, 252, Article 112117. https://doi.org/10.1016/j.rse.2020.112117

Sulaeman, Y., Poggio, L., Minasny, B., \& Nursyamsi, D. (2020). Tropical wetlands-innovation in mapping and management. International Workshop on Tropical Wetlands: Innovation in Mapping and Management, 2018, Article 197. https://doi.org/10.1201/9780429264467

Traore, M., Wambo, J. D. T., Ndepete, C. P., Tekin, S., Pour, A. B., \& Muslim, A. M. (2020). Lithological and alteration mineral mapping for alluvial gold exploration in the south east of Birao area, Central African Republic using Landsat-8 Operational Land Imager (OLI) data. Journal of African Earth Sciences, 170, Article 103933. https://doi.org/10.1016/j.jafrearsci.2020.103933

Xing, L., \& Niu, Z. (2019). Mapping and analyzing China's wetlands using MODIS time series data. Wetlands Ecology and Management, 27(5), 693-710. https://doi.org/10.1007/s11273-019-09687-y

Zabloskii, V. R. (2019). The method of detection of clay minerals and iron oxide based on landsat multispectral images (as exemplified in the Territory of Thai Nguyen Province, Vietnam). Mining Science and Technology, 4(1), 65-75. https://doi.org/10.17073/2500-0632-2019-1-65-75

Zhai, M. (2019). Inversion of organic matter content in wetland soil based on Landsat 8 remote sensing image. Journal of Visual Communication and Image Representation, 64, Article 102645. https://doi.org/10.1016/j. jvcir.2019.102645

Zribi, M., Baghdadi, N., \& Nolin, M. (2011). Remote Sensing of Soil. Applied and Environmental Soil Science, 2011, 1-2. https://doi.org/10.1155/2011/904561 
